PART SIX

THE VICTIMS 
Hans Derks - 9789004225893

Downloaded from Brill.com@4/26/2023 09:53:26AM via free access 


\title{
BLAMING THE CHINESE VICTIMS
}

\begin{abstract}
'... the use of opium is not a curse, but a comfort and benefit to the hardworking Chinese; that to many scores of thousands it has been productive of healthful sustentation and enjoyment.'

Messrs Jardine, Matheson \& Co, opium dealers (1858). ${ }^{1}$

'We forced the Chinese Government to enter into a treaty to allow their subjects to take opium.'
\end{abstract}

Sir Rutherford Alcock $(1871)^{2}$

\section{Introduction}

To introduce this last part, it is necessary to explain in a few words why and how victims have played an important role in this History of the Opium Problem. The obvious answer almost suffices: because the manysided historical description of it above highlighted the kinds of institutionalized perpetrators who cannot act normally without making opium victims. They are mutually dependent on each other; they constitute a relationship. Thus, a description of the victims' positions must follow to create a comprehensive story and make a complicated definition of an Opium Problem possible (see part 7). Although this history could be called "perpetrator oriented", one may hope that this more or less abstract introduction and the following chapters provide enough compensation to give the alternative a reasonable profile.

As announced, in this book a "productive approach" of the Opium Problem in history was chosen: in short, for describing and analyzing the political economy of the problem mainly in the framework of Western imperialism and colonialism. Therefore, the relations between perpetrators and victims are perceived in this same framework. They differ greatly,

\footnotetext{
${ }^{1}$ J. Beeching, p. 263 combined with the slightly different wording in J. Spencer Hill, p. 31.

${ }^{2}$ Quoted by W. Willoughby, vol. II, p. 1094.
} 
of course, in the development of the Opium Problem in European countries from which these perpetrators came. The relationship changes drastically in both histories but remains intact as indicated, for instance, in the image: the snake which bites in its own tail.

In this "productive approach" victims cannot be perceived as such, nor their suffering, while certainly solutions for their sorrows cannot be given without referring to the reasons for their addiction. Analyses, descriptions or explanations in a "productive approach" inevitably point to the role of the state and its bureaucracy, military and police; large economic interests; opium production, trade or marketing; legitimising thoughts and so on. We only arrive at the victims and their personal and dramatic stories as derived from these "acts".

The opposite is much better known in narco-literature. It can be called the "consumptive approach", which starts with the personal sufferings of addicts and proceeds with the success or failures of their cure by religious, medical, social or bureaucratic (police) workers; the success or failure of the state to protect society from this drug menace which costs the taxpayer astronomical amounts of money. The bad guys, the mafiosi, are promoted as the most "beloved" targets in films, books or theater. This approach is, as a rule, much more personal and emotional. In my view, it is the main reason why a comprehensive picture of the social, economic or political backgrounds of these dramas is seldom arrived at (or not).

It is logical that in this part Chinese victims, as the most spectacular of all opium victims of the West, receive special attention within the framework of a "productive approach". Therefore, no pictures of emaciated Chinese addicts sucking on their pipes in opium dens managed by other mysterious Chinese, which were spread after $185^{\circ}$ through all Western dailies and books for ambiguous reasons. Indian, Southeast Asian or Indonesian addicts do not show up often. What will be discussed is, I hope, appropriate also for these victim countries: China represents here an "Oriental model", an image which was (and often still is) not at variance with the existing "Orientalism" in the minds of many or most Western observers.

To choose the example of China as a victim country (Chinese victims are derived from it, therefore) was not difficult since no other country was attacked from all sides and by all Western countries including Japan: all expected to find there the most abundant sources of wealth. The attacks involving opium and weapons were as long-lasting and heavy as the expectations were great and the disappointments severe: there were many reasons to blame Chinese victims! 
Understanding the victims' positions on this level, however, is not easy. How tricky a victim-perpetrator connection can be is demonstrated in the ongoing discussions concerning the most "spectacular" modern example, the ambiguous relation between Israel and Holocaust victims. ${ }^{3}$ Through a notorious decision of the United Nations (1947), the pre-war Zionist and Jewish settlers of the British were allowed to establish a new state in Palestine and expelled nearly a million persons of the indigenous population and exploit and repress the remainder of these Palestinians on a massive scale. In the end the only legitimation or pretext was that some of its newly imported Europeans with a Jewish or Zionist background were victims of the Nazi regime (never more than $8 \%$ of the new Israeli population). One of the most unfortunate effects was that the Holocaust victims' position was immediately degraded through its use as a tool in an internationally criticized foreign and internal policy or, worst, as revengeful new perpetrators.

Many other examples can be given (Balkans, Kashmir, Rwanda, etc.) in which victims later became stupid perpetrators as well, forgetting which kind of injustice was done to themselves. Revenge at this level always means a bloody, long-lasting and difficult to pardon collective affair. In looking for solutions, one can never forget the reasons for all this bloodshed before blaming the original victims.

A victims discussion should be concentrated on the case at issue and on the right level. In this book, therefore, this is something like "massive addiction through opium by external (military) powers from the West during one and a half or three centuries". The roles of perpetrators, European and Chinese criminals and authorities alike should be highlighted as well on the same general level. Objections could be raised and criticized.

Under the influence of present positions or developments (from after 1950, the last year of this History of the Opium Problem), some scholars produce rather harsh judgments about a pre-1950 history. It is too easy to transform this into a demagogic trick. A scholarly discussion has to remain as "clean" as possible: we should, at least, differentiate between occasional expressions of someone's emotions and structural elements of a phenomenon; it seems obvious not to blame a whole society for the misdeeds

3 H. Derks (2004), chapter 6 and 7. How ambiguous this relation is follows from the writings of Israeli historians like Tom Segev (The Seventh Million) and Idith Zertal (Catastrophe to Power) or, more recently, from Hajo Meijer (The End ofJewishness). 
of one inhabitant or of a specific (criminal) coterie, and it is less obvious, but very understandable, not to blame earlier "good behavior" under the influence of later "bad behavior".

In blaming people, pejorative language is often used, while discrimination is normal. Here are two examples of how not to discuss our case ('blaming Chinese victims'): the first concerns my own writings below and the other is related to the highly interesting scholar Frank Dikötter, who seems to point to "Chinese racism" as a kind of excuse for Western racism. Below we shall discuss the main elements of this Western racism vis-à-vis China and the Chinese to show how untenable this position is.

An enthusiastic peer reviewer of this History of the Opium Problem also remarked in passing that I should avoid 'subjective comments' like 'mafia' when referring to the Jardines and Sassoons: 'they were simply doing what they knew how to do best, trade by all means, just like their Chinese counterparts'. Still, I decided in ch. 31 below not to alter this 'mafia' because of the many similarities to the classical and original mafia and to stress the remarkable position of these and similar gentlemen.

For decades both the Jardines and Sassoons were involved in the illegal drugs trade, smuggling, probably piracy. Later, when the former left the opium business, the Sassoons became increasingly involved in pure modern gangsterism (see below). Indeed, this was 'trade by all means' and on purpose, but normal trade is by definition peaceful and legal and not involved in illegal products which are seen officially and by Jardine himself as immoral-also in the beginning of the 19th-century. The many Chinese prohibitions, the debates in the English Parliament at the time or the discussion with Gutzlaff (ch. 6) are illuminating in this respect.

The Sassoon family, even more than the Jardines, Mathesons or Dents, was indeed a family (the classical meaning of 'mafia') which cooperated with similar criminal 'families' like The Ezra gang. Last but not least, all of them were knighted and arrived in the position of all later drugs-barons. Altogether, there are quite objective reasons to use a label like 'mafia'.

The Dikötter example is more important as an excellent representative of the "consumer approach" as defined above. Here it concerned his use of "racism", a qualification often used when blaming victims. Dikötter tries to prove his case by extensively quoting some journalists and an "Overseas Chinese", Su Xiaokang (1991). This person, living in the USA, sees "Chineseness" primarily as a matter of biological descent, physical appearance and congenital inheritance: one is Chinese 'by virtue of one's blood', 
whatever his/her social background, birthplace in this immense country, profession, ethnic allegiance, language, etc. ${ }^{4}$

It is already remarkable that Dikötter pays attention to this fully outdated and controversial opinion, knowing its consequences when used at state levels and in state propaganda. He also quotes two other examples: a very primitive form of racism relative to black people in the writings of Kang Youwei (1858-1927) $)^{5}$ and a pure reproduction of anti-Chinese racism transformed into a positive exclamation about his China ('The greatest force is common blood', etc.) of Sun Yatsen (1866-1925).

The former is perceived as a monarchist or a reactionary virtuosi but, in my view, he is a perfect example of a national-socialist ideologue. Anyway, in China he is also considered a highly controversial political thinker. It is not necessary to criticize Sun Yatsen, father of the Chinese Republic, for his occasional statement. In a European racist discourse, however, his dictum that 'the Chinese belong to the yellow race' can only be supported by radical racists (see below).

Dikötter's aim with this discussion remains unclear and is based on very shallow grounds. Youwei's and Sun Yatsen's opinions reproduce the modernized Western ideological choice in China around 1910. I cannot discover more than a concern about present African students, who are 'periodically' subjected to racial attacks at some Chinese university, or about Tibetans and Uighurs who are officially discriminated also on racial grounds. To relate Sun Yatsen and the other to African students or Muslim Uighurs is a "mission impossible".

No context or proportionality of the case is given. Racism in a country with hundreds of ethnic minorities certainly exists locally, but it must be underdeveloped in all respects and cannot be equated with "Chinese Racism”. For instance, tensions between local Han versus other tribal peoples are expressed high in the north in Chinese Mongolia but also in the deep south (see Yunnan below): they are fully unrelated and not comparable since the local circumstances are very different for all parties involved. Only outsiders can construct some commonalities.

Compared to what the enlightened societies in Europe, the United States or Australia demonstrate at present in this respect ("gypsies" are still killed in several East European countries like the Mexicans along the border with the USA; people with an Islamic belief are seriously discriminated against in nearly all Western Christian countries, and so on); com-

\footnotetext{
4 F. Dikötter, B. Sautman (ed..), p. 1.

5 See D. Leese (ed.), p. 118-121 and passim.
} 
pared to all this, "racism of some Chinese" must be seen as insignificant. 6 This, however, can never be an excuse for acting in a racist way or being silent about it.

Concerning the opium use itself is Newman's and his pupil Dikötter's argument of interest

that nineteenth century opium use was a pleasurable and largely harmless aspect of popular sociability and that relatively few users were addicted. ${ }^{7}$

Newman's remarkable view is discussed below. Here I refer only to the relevant criticism of Harrison who points to the untenable downplaying of the socio-economic effects of drug use. Her research in the Shanxi villages reveals how the effect of drug taking on rural family finances was often devastating. It is also important that she considered the transition from opium to refined narcotics like morphine and heroin as a problem in its own right.

The last thing one should say about the drug-scene in post-1911 China, as described below, is that it concerns 'a pleasurable and largely harmless' constellation! Anyway, in this way the case of the opium victims was blurred by unnecessary "noise". The obvious question is now how and why are the Chinese opium victims blamed for "their" sins?

\section{An original Image 8}

There is the indestructible image of "the Chinese" as both opium producer and addict formed from about 1870 onwards. Pictures of Chinese smoking pipes in an opium den were an absolute hype in all dailies and illustrated journals. In the 1960 overy flu was called a Mao-flu. Even in the 1970 s in the Netherlands and elsewhere, using heroin-a typical

6 Dikötter should listen to F. Dikötter (1995), p. 6, where this author warns: 'It is dangerous to reduce the cultural categories of a period to the expressions of a dozen authors, and the hagiographic conventions which endlessly parade figures ...' All this cannot have the aim to disqualify Frank Dikötter (and his co-authors). Below, many excellent publications by him are used, and F. Dikötter, L. Laamann, Z. Xun is a highly informative tome concerning the "consumptive approach", the alternative of the "productive approach" adhered to in this History of the Opium Problem.

7 H. Harrison, p. 154. It is a pity that I came across Harrison's long article too late to use it in a proper way below. I am anyway glad that she can support my rather positive conclusion about the role of the Communist Party in eradicating the drug culture in the 1950 os (see p. 176).

8 See for more background the article of Andreas Pigulla in: D. Leese (ed.), p. 110-113. 
European chemical product - was called 'chase the dragon' and even 'to chinese'. Heroin itself is also named 'Chinese White', notwithstanding its invention and exploitation by German-American pharmaceutical firms like Merck or Bayer.

An older and well-known characteristic is of the Chinese or China as Weltfremd, isolated from the rest of the world. We have already met this time and time again. It was evident in the English offensive which already started at the end of the 18th-century in McCartney's opium mission. Not much later seducers like the opium dealers Jardine, Matheson \& Co, Sassoon, Dent and politicians from Palmerston to John Adams attacked the Chinese reluctance to accept opium as dangerous isolationism, xenophobia, anti-Western and anti-free trade enmity and so on. Old and new prejudices and half-truisms were mixed up to win a propaganda battle in which the real victims became transformed into the offenders. Present historians continue too often in this mood, as quoted in the Preface, or by declaring out of the blue that opium

was ... an essential part of the lifestyle of millions of Chinese, for whom opium smoking was a social relaxation, a release from pain or a temporary escape from a miserable existence. With such an insistent demand for the drug ... the opium trade was able to continue into the twentieth-century despite official disapproval in China ...9

However, from about 1900 onwards, not only Chinese governments but all kinds of Chinese victims from Nationalists and Communists to Republicans started to organize all forms of protest against opium-imperialism: it was foreign to Chinese traditions and cultures, as well as being an economic assault destabilizing society. It is the time when industrialization and urbanization created a large Chinese audience for these complaints.

Foreigners reacted with a virulent racism. This was widespread in the United States, Europe or Australia and not confined to foreigners in China. It made serious victims among the overseas Chinese as well. It is from this time that China definitely took another direction of development and very quickly became a highly distinctive society. And 'never the twain shall meet', Kipling's famous dictum, was repeated time and again, as if there existed a necessity to do this. ${ }^{10}$

\footnotetext{
9 R. K. Newman (1989), p. 525, 526.

10 See an interesting discussion around this subject in M. Jacques.
} 
Something of these images was true for the simple reason that the Chinese territory was as large as Europe, and they never could "handle" more. We do not accuse the ancient Romans of conquering only half of Europe or of knowing nothing of the Chinese. They were contemporaries of the Qin and Han dynasties, the Great Walls of which attract more tourists than the Colosseum in Rome, let alone the Hadrian's Wall in Britain. Like the Romans, the Qin and Han were always busy with border conflicts as a routine matter, so why not perceive the attack of the 'foreign white devils' as just the next border conflict?

This kind of reasoning is largely nonsense; underestimating its propagandistic "value" in the intolerant Christian societies is unwise as well. A remarkable example of its impact can be found early in the quite learned, liberal and Lutheran Staatswörterbuch (1857) in which one can read a theory about "the" Chinese: they are not the original people, but invaded the present area thousands of years ago from the Northwest, ousting the original people to the periphery before they themselves arrived at last at the coast:

Because they were from time immemorial an agricultural people from the interior and surrounded by uncivilized tribes, the Chinese only could develop themselves without any impulse from outside. Thanks to this situation the Chinese people became one-sided, limited, extreme conceited [dünkelhaft eingebildet] and remained so after arriving at the coast of the wide ocean: still they communicated insufficiently with other less cultivated peoples like themselves ...11

And when "the" Chinese started such a distorted communication, they could not learn anything from the other, 'not in agriculture, industry or trade and not in religion, art or science'. This is, of course, incompatible with modern science from the beginning to the end, but still a substantial part of the discriminating "yellow race theory".

It is only possible to come up with general characteristics of "the" Chinese if one takes the impossible bird's eye view in which all Chinese are treated alike. Even after the long-lasting, unifying influences of the $\mathrm{CCP}$ - rather unique in Chinese history - there are currently hundreds of different ethnic groups with rather contradictory characteristics (from language to lifestyle or economic performance) and remarkable differences between hundreds of regions of this immense country.

Let's first take opium as "typically Chinese" to demonstrate the untenability of this generalization.

11 J. Bluntschli (ed.), vol. 2, p. 440. 
Long before the British, French, Dutch and other traders and smugglers did their rather nasty work in the Chinese realm against the will of Chinese governments and laws of the country, opium was used in China as medicine. We can safely conclude that until the arrival of the 'foreign devils', a select group of Chinese (in a select part of this vast country) used opium in very small quantities among the hundreds of other vegetable medicines. And probably, who knows, a few became addicts. They could buy it and learned how to handle it from Arab caravan traders or from the many visits of Chinese fleets to the lands in the Indian Ocean or Arabian Sea.

Another use of opium in China was in some religious rituals like those concerning the Tsao Wang or Kitchen God in North China. He is one of the oldest household deities who 'looks after the hearth' and 'has constituted himself the censor of morals of the family'. As such, he is perceived as 'the connecting link between God and Man' who makes an annual report about the family to be laid before the All Highest. ${ }^{12}$ To make this report as favorable as possible and to ensure that he will say only kind things or even to silence him altogether, the mouth of his picture or sculpture is smeared with something like opium (in other cases one used wine) to render him drowsy at the time of making his report.

During the Manchu era there existed a sect of girls in some secret guilds like the 'Golden Orchid Society' who vowed never to marry. Breaking their celibacy by enforced marriage regularly led to suicide by using white arsenic or opium. ${ }^{13}$

A rather famous historian of Chinese history, Wolfgang Eberhard, wrote: 'The Chinese were familiar with opium under its Near-Eastern name, afyûn (a-fu-yung) probably since Sung times. ${ }^{14} \mathrm{He}$, first, cannot provide any proof for this and uses 'the' and 'familiar' as if all Chinese at the time knew about all forms of the drug. For a period of at least four hundred and at most seven hundred years later, Eberhard continues the former quote with the first concrete and very symptomatic information:

In the Ming era, the emperor received 200 pounds for himself and 100 for the empress from Thailand, but from the eighteenth-century on, opium arrived in China from the coast. At the time of Ch'ien-lung [1711-1799; H.D.], the court received between 200 and 1,00o crates from the Portu-

\footnotetext{
12 V. R. Burkhardt, vol 1, p. 76, 77.

13 Idem, p. 108.

14 W. Eberhard, p. 298 also for the following quotation.
} 
guese. In 1729, the government confiscated 34 pounds in the storeroom of a merchant in Chang-chou (Fukien). Thus, opium is not a drug, recently imported into China, but has a long history in China.

The opium presents for some Ming emperor and his wife were apparently nothing but an accident in a period of three hundred years and did not affect the 200 million Chinese inhabitants at the time. The information tells us also about who gave the opium: indeed, 'foreign devils'. Their big opium present was enough to addict the whole court and, anyway, aimed at provoking an opium market. We do not know whether it was repeated, but it was confined to the court only and had exactly the "wrong" effect: the emperor started a new offensive against opium from 1729 onwards! And that for a ridiculous quantity of 34 pounds in the house of a coastal merchant several thousand miles from the court? Perhaps this was not as ridiculous as it seems, because the next information is about the other classical phenomenon around opium trade: smuggling of the now prohibited substance and illicit distribution from the coast to some interior.

During the Yongzheng reign in four coastal prefectures, sworn brotherhoods started their organized criminal work in the use and distribution of opium around $1755 .{ }^{15}$ As usual, their work also led to fierce village conflicts in those prefectures, reason enough for a government to interfere. At this time the only sources of the opium were Bengal and some Middle Eastern locations, while the trade was largely a monopoly of 'foreign devils': Dutch, English or Portuguese traders from Macao. In a mild form (compared to what happened in the next century ${ }^{16}$ ), all the ingredients of the Opium Problem were available: foreign opium assaults versus government defence and in between, the market battle of smugglers and criminals concerning a very small and illicit market.

Until about $175^{\circ}$ it cannot be true that Chinese other than courtiers and the well-to-do used opium sometimes as a luxury or that some physicians knew how to use it as a medicine if it was available to them. The other ritual uses of opium mentioned are confined to very specific occasions or locations from which it is uncertain whether it was really opium of the many available herbal remedies (raw, prepared?) which was used.

Indeed, from about 1790 when the British and other opium traders arrived for the first time in Canton, everything changed in a fundamental way: the new era of mass-produced and mass-imported illicit opium had

\footnotetext{
15 J. Lipman, S. Harrell (ed.), p. 43.

16 See also idem, p. $5^{2}$.
} 
arrived, the smokers followed. Not only governments but also the Chinese opposition, the most spectacular being the Taiping, were against opium production and consumption:

Although opium had been smoked in China for many years, it became a serious problem after the beginning of opium importation from India. Taiping leaders had witnessed the smuggling of opium and the resulting Opium War as well as the demoralizing effect the smoking produced among the people. China's defeat in the Opium War must have given them an added cause for wanting to eliminate all opium smoking. ${ }^{17}$

So, telling an uninformed Western audience that the "Chinese knew about opium already for centuries before we arrived" as an obvious defense of their own criminal activities is one of those examples of the political use of generalizing statements and of a bad Western consciousness.

Next, we fix the beginning of the Opium Problem in China during the British and other Westerners' gradual organization of the assault in the First and Second Opium Wars. The details are discussed in part 2. Palmerston's operations, the failed opposition of Gladstone and others, and the hypocritical way treaties were made with China and immediately broken are sketched. The follow-up is also completely under the constant pressure of the English. An example from an insider:

During the years immediately following the Opium War, the British Government made repeated efforts to induce the Chinese authorities to legitimize the importation of opium into its borders. Lord Palmerston, in 1843, instructed the British representative in China "to endeavor to make some arrangement with the Chinese Government for the admission of opium into China as an article of lawful commerce"; and advised Sir Henry Pottinger that he should "avail himself of every possible opportunity strongly to impress upon the Chinese plenipotentiary ... how much it would be for the interest of that Government to legalize the trade. ${ }^{18}$

Pottinger started his networking through private conversations with the Chinese anti-opium commissioners. The latter asked the Englishman why the foreigners would not act fairly towards them by prohibiting the growth of the poppy in India and thus effectually stopping 'a traffic so pernicious to the human race'. Pottinger's answer is worth recalling:

17 V. Shih, p. 226. Poems were made to express the hatred for opium and opiumsmokers (id., p. 228); the Taiping social policy was wholly directed toward the prohibition of opium (id., p. 443); opium smokers were simply threatened with execution (id., p. 70).

18 W. Willoughby, vol. II, p. 1092; J. Rowntree, p. 68-73 about the "negotiations" of Sir Henri Pottinger. 
This, he said, in constituency with our constitutional law, could not be done; and, he added, that even if England chose to exercise so arbitrary power over her tillers of the soil, it would not check the evil, so far as the Chinese were concerned, while the cancer remained uneradicated among themselves, but that it would merely throw the market into other hands. It, in fact, ... rests entirely with yourselves. If your people are virtuous, they will desist from the evil practice; and if your officers are incorruptible and obey your rulers, no opium can enter your country. The discouragement of the growth of the poppy in our territories rests principally with you, for nearly the entire produce cultivated in India travels east to China. If, however, the habit has become a confirmed vice, and you feel that your power is at present inadequate to stay its indulgence, you may rest assured your people will procure the drug in spite of every enactment. ${ }^{19}$

It is an answer worth of a diplomat of "Perfide Albion": blaming the victims for everything at the end of the First Opium War, while negotiating the Treaty of Nanking (1842), the most humiliating treaty the Chinese had to sign. As a reward for his service, Pottinger became the first governor of Hong Kong, from then on the center of the opium trade.

Notwithstanding the financial temptation to follow this diplomatic language of a narco-military order, the Chinese emperor refused to take the step to legalize opium. He even replied:

It is true that I cannot prevent the introduction of the poison; gain-seeking and corrupt men will, for profit and sensuality, defeat my wishes; but nothing will induce me to derive a revenue from a vice and the misery of my people.

A new Opium War and new humiliations further, the Chinese still retained their objections. ${ }^{20}$ The possibility to connect practical consequences to

19 Quoted in J. Rowntree, p. 72, 73 from the diary of a Captain Loch, author of Campaign in China (ca. 186o). Rowntree adds that he hoped the Chinese had insufficient knowledge of "our constitutional law", so that they were debarred 'from following the extraordinary propositions' of Pottinger.

20 It remains an incredible coincidence that the English commander responsible for the Second Opium War and the most serious devastation, Lord Elgin (the son of the Elgin who had stolen the Karyathides from the Parthenon in Athens, whereupon they were called the "Elgin Marbles"), later showed strong disapproval of the opium traffic and of the two wars which were unjustifiable upon the part of the British Empire (quoted in Idem, vol. 2, p. 1094). He wrote in his memories: 'I have hardly alluded in my ultimatum to that wretched question of the Arrow which is a scandal to us, and is so considered, I have reason to know, by all except the few who are personally compromised.' And elsewhere: 'I thought bitterly of those who for the most selfish objects are trampling under foot this ancient civilization.' Etc. See J. Beeching, p. 318 about the destructive plundering of Peking by the English and French. The disgust of Lord Elgin is worthless since he was responsible for the conduct of his soldiers. 
this moral appeal, however, was bombed out of their hands. Forty years later as the agitation in England against the constant opium imports from India reached considerable proportions, the absurd attempt was made to blame the Chinese themselves: 'to show that the legalization of the importation of opium had been freely assented to by China'. ${ }^{21}$

Half a century after the last war China could repeat its criticism with some initial success. It definitely succeeded in solving its Opium Problem after 1949. It is, therefore, worth considering the following question.

\section{Who and How in the Chinese Opium Scene}

After the opium wars, the important territorial losses, the huge payments and so on, the anti-opium campaigner Joshua Rowntree (1906) concluded nearly correctly:

Great Britain had at last accomplished its desire, so long worked for, so little avowed. The Government of India was no longer to be the chief accomplice, the unsleeping partner of Chinese smugglers. The great drug trade was regularized by law. China had yielded to steady, continuous pressure, which it had not the strength to resist. ${ }^{22}$

This is nearly correct since these "Chinese smugglers" were the small fish in the English and American business of Messrs. Jardine, Matheson \& Co, of the Sassoons or the Russells.

It is also obvious that once the foreigners imported opium into the coastal ports, there was a need for some Chinese merchants to bring it into the interior, if they were convinced that it was profitable to do this. Here the foreigners practically created a new opium market and found willing customers. The means to do this involved corrupting key-persons in bureaucracy or trade (direct contempt of law), smuggling and keeping every phase of the process in their foreign hands, (in)directly threatening foreign revenge.

Take the example of the coastal port of Tianjin in the north directly on the road to Beijing which received (in)directly foreign import in the 19thcentury:

21 W. Willoughby, vol. II, p. 1094. A most important contribution to this problem is G. Lee, who started from the pioneering Berridge-Edwards study used above at the end of part 2.

22 J. Rowntree, p. 93. 
... foreign goods and foreign opium. Merchants from the interior sold their products in Tianjin and bought opium with the proceeds; just before the Opium War, Tianjin was the central point for drug shipments into North China. ${ }^{23}$ 'In the first years of the treaty port ... opium and cotton cloth dominated the import trade. From the end of the Sino-Japanese War (1895) to World War I, the scope of foreign activity in China greatly expanded. In Tianjin the net volume of foreign trade increased, in spite of reduced activity during the Boxer Rebellion and the last few years of the Qing dynasty. Cotton yarn, cloth, sugar, kerosene, dyes, and opium were the major imports. During and after World War I, many foreign firms began to import military hardware for warlord customers. ${ }^{24}$

This shows the differences between the beginning of the 19th-century and the end. But it is too easy to think that the Chinese merchants simply bought the stuff at the quay or embankment and departed for the interior as missionaries suggested (see below):

From 1860 until 1949, foreigners controlled every stage of the passage of goods into and out of the port of Tianjin. ${ }^{25}$

Here "every" must be stressed because their control covered the customs service, foreign loans and money, ships (mostly owned by the British and later by the Japanese), shipyards, the business of unloading ships, transferring the cargoes to barges destined for the interior, and so on.

Actual trading was carried on by the foreign-owned yanghang, which usually hired a Chinese comprador to act as agent with native merchants. ${ }^{26}$

An insider, an important civil servant of the British Empire, Maurice Collis (1889-1973), reminds us about the early 19th-century start of this business in his history of the opium trade and opium wars:

The Company [the EIC] controlled the cultivation of opium in India, having in fact almost a world monopoly of the drug. The eleven million dollars sold by the country firms in China was procured at Company auctions held annually at Calcutta. Thus, the Company was the source of the opium traffic. ${ }^{27}$

Again foreigners controlled the proliferation of the drug from the earliest stage, not only the foreign merchants and their factory helpers in Canton, but also missionaries were 'attractive potential allies for merchants while

\footnotetext{
23 G. Hershatter, p. 12.

24 Idem, p. 26.

25 Idem, p. 27.

26 Idem, p. 27.

27 M. Collis, p. 71.
} 
also giving accounts of their mission a literary appeal' and by influencing 'the crafting of foreign policy for the Opium War as the political situation in China intensified due to opium trafficking'. ${ }^{28}$

A century passed between this start and the situation in Tianjin. Yet present historians still blame the Chinese. For example, the simple comment made by amateur historian Priscilla Napier. She excuses, first, the EIC's opium monopoly as 'a necessity' thanks to the Napoleonic wars, and she continues with:

At the other side of the world, thousands of South Chinese seemed unwilling to endure the continuous toil, poverty and hardship of their lives without opium's instant but fatal alleviation. ${ }^{29}$

The following reasoning of a professional historian about the situation at the end of the 19th-century is already more sophisticated:

Western liberals and missionaries argued with growing passion that the West was guilty of corrupting China. The Chinese said Western opium was deeply responsible for China's weakness and decline. None of it was true. What was keeping Chinese from Christianity was Christianity, which was deeply subversive of China's social order, while the people preaching it were of course foreign agents. The truth was that no one, Chinese or foreigners, knew how to persuade Chinese not to grow or use opium. Still less could anyone prevent foreign merchants from shipping it into a very willing market. In any case, the great majority of China's opium supply was by the 1860 s and ' 70 s being grown at home. One guesstimate is that by 1900 there were about 40 million consumers of opium in China, about $13 \cdot 5^{-1} 5^{\text {million }}$ of them addicts. ${ }^{30}$

Let's say it again: from early on, opium was imported into China; it was not home grown. That was the case in the 16 th and 17 th-centuries when opium was imported from the Middle East as medicine. This is fully irrelevant for Gelber's reasoning, however. Opium as a result of "legal" Chinese poppy growing started after the two Opium Wars.

Before those events Chinese who tried to produce opium or to grow poppies risked being killed because it was not only forbidden by Chinese law, but there was also an active prosecution and repression from, at least,

28 B.L. Fischer, abstract.

29 P. Napier, p. 65. Elsewhere (p. 91) she gave another classical "argument" in the framework of "blaming the victims": "Although the Chinese had been growing and eating opium on a minor scale since the 70os, the habit of smoking it on a considerable scale did not begin till the 17 th-century.' No source is mentioned for this wisdom.

30 H. Gelber, p. 223, 224. For alternative consumption figures see Idem, p. 451, $45^{2}$ note 8 . 
around 1800 onwards. Foreign merchants were prevented officially from importing opium, whereupon the 'foreign devils' (mainly English, Englishbacked Indians and Americans) organized extensive smuggling activities.

As this illicit trade became effectively blocked by the Chinese authorities, the English (supported by the French) opened up the opium market by the use of substantial military violence. That is the truth which is not only neglected by Gelber and others, but actively denied since he also claimed that the Chinese 'emperor decided to make war on the laws of supply and demand'31 or that the Chinese 'did want to buy more ... opium from India'32 instead of pointing to the cutthroat consumption to which they were destined by the English in the 19th-century.

Whether, furthermore, Chinese opium was home-grown during most of this century cannot be concluded from the previous analyses. In the next chapter the Chinese consumption pattern will be discussed in all possible detail with nearly the same result. Still, a major question remains unanswered: who owned, initiated or financed this poppy cultivation in China? This would be a good research project for Chinese scholars.

Thus, many "foreign devils" knew perfectly well how to make some Chinese into opium addicts: by military violence, by importing mass-produced opium and by organizing the supply far into the interior by various means (see the Tianjin example). Of course, it is self-evident that after 1860 producers started to grow poppies in Chinese regions where this was possible like Yunnan.

However, it is easily forgotten that prolonged military violence was needed in one way or another: not only the Opium Wars or the rather continuous fights against smugglers of all sorts, but the very rebellious period also caused warlords to stimulate or organize opium production and trade to pay for their weapons and keep their soldiers satisfied. That started during the Taiping and other revolts and continued after 1900 to 1945 (see ch. 31).33

31 Idem, p. 186 which contains also a nearly explicit defense of the British assault: the smuggling of opium (by the British, etc.) is 'China's problem, no one else's', etc.

32 Idem, p. 173 .

33 Regarding the warlord practice, Gelber reports only one case (p. 275), the alleged Mao's opium trade, without mentioning any source. He not only neglects the overwhelming practice of trade in opium and other narcotics of Chiang Kai-shek and other warlords, he also neglects the professional literature of - say-a profound drugs and Chinese historian like W.O. Walker III, chapter 4 and 5 . If Mao dealt in opium, Walker should have mentioned this immediately (with sources!). See also C.Trocki (1999a), p. 134 who mentions for this one source, but of a suspect kind, a young American author, E. Devido, without further experience except in Taiwanese and Buddhist relations. 
In short, it is purely blaming the victims to suggest that "the Chinese" formed a 'very willing market' or that 'nobody knew' how to stop this mass addiction. It was nearly stopped between 1908 and 1918,34 and it certainly was stopped after 1945 by the Maoist regime: by ending foreign opium import; by harsh measures against the Chinese producers and traders; by mild but firm procedures for the addicts. In a few years time the opium problem belonged to the past in China! In the century before this remarkable date, it seemed as if the whole world was attacking and addicting China from all sides and with all possible weapons, as will be demonstrated below.

\section{The Religious Assault}

Blaming the Chinese opium victims was also a result of Western religious activities. ${ }^{35}$ It was remarkable that clergymen like the Reverend Charles Gutzlaff were highly active in spreading opium by means of the Holy Cross. This is documented also in Maurice Collis's report about the relationship between Gutzlaff and the opium tycoon Jardine. ${ }^{36}$ The aim of the priest was so high,

to convert to Protestantism at last the teeming millions of a country, which for millenniums had been plunged in darkness, and bring to it not only light and truth but the uncounted blessings of free commercial intercourse with those chosen nations to which God had revealed Himself. As Mr. Jardine had so truly said, the exchange of commodities more respectable than

${ }^{34}$ As is apparently proved by J. Madancy, but see R.K. Newman (1989) and next chapter.

35 That is not new information: an unexpected announcement comes from the German race theoretician $\mathrm{W}$. Schallmayer, p. $283 \mathrm{ff}$. who provides numerous examples of the low intellectual level of missionaries, their irritating behavior always under the umbrella of foreign arms, the many unfounded prejudices and disdain for the Chinese culture. His main target is the famous American missionary and author A.H. Smith, and his main support is apparently the one-liner of Prince Kung (ca. 1870): 'Do away with missionaries and opium, and our mutual troubles are gone as well!' In addition, Schallmayer criticizes the very superficial knowledge about China among the German population.

36 M. Collis, p. 82 ff. For Gutzlaff see also C. Carr, p. 47 ff. and Th. Klein, R. Zöllner (ed.). This last reader shows that it is easy for Gutzlaff to substitute the qualifications "stubborn colonial bureaucrat", "fundamentalist missionary", "non-scrupulous merchant in East Asia" or "marketing genius". Indeed, these qualifications concentrated in one person, named Gutzlaff, deliver the appropriate range of attitudes demonstrated by the foreign missionaries in China or other parts of East Asia. It is far from a 'natural inclination' of missionaries to condemn opium consumption as R. Newman, p. 768 thinks. See recently B.L Fischer, chapter IV, p. 245-355 about Gutzlaff, in particular 'Gutzlaff, Opium Merchant', p. $261 \mathrm{ff} ., 322 \mathrm{ff}$. 
opium was impossible unless funds were provided by sale of the latter. And there must be commerce if there was to be evangelization; the two were indissolubly bound together. ${ }^{37}$

Collis stresses that we must not forget that the 'rubbish' this reverend and his tycoon communicated was the opinion of the largest majority of the English and far beyond: the EIC, the Parliament, all Europeans held the conversion of the Chinese to Christianity 'to be highly desirable'. Notwithstanding our knowledge about this religious adventurer with his extensive opium network, it is still a remarkable surprise for present-day Christian historians when one discovers:

Westerners and opium were associated in the minds of the Chinese, who blamed the foreigners for bringing opium to China and addicting the Chinese to it in an effort to weaken them so that Westerners could gain more privileges from the Chinese government. ${ }^{38}$

Immediately after this correct conclusion Lodwick, who aims at describing the heroic fight of American Protestant missionaries in China against opium, neutralizes this statement in the classical Christian way by insisting that

smuggling opium into China in the early years of the nineteenth-century could never have taken place if Chinese themselves had not been the foreigners' accomplices who transported the drug into the interior for sale to other Chinese.

This almost incorrect conclusion (see previous section) leads directly to the old game of blaming the victims, who must anyway be converted to a foreign belief system: they are sinners, and if they could be converted to this Christianity (a project that was too difficult and unsuccessful, as was generally the case throughout Asia), they remained an inferior kind of Christian because the so-called "yellow race" was "racially impure" for too many Europeans and Americans.

This ends also in the classical mistake of substituting the behavior of some individual Chinese for that of the whole nation, culture, etc. and the reverse. Basic to these mistakes are the attempts (often deliberate) to

37 M. Collis, p. 84.

38 K. Lodwick, p. 2. In fact, the same opinion as Gelber as quoted above. The very American Protestant B. Fischer, who has many interesting things to say about Gutzlaff's opium gospel + bible books business, also demonstrates why historical understanding must fail here: he remains preaching against the sinner Gutzlaff. The latter did not understand that 'the good news that Christ's atoning sacrifice was available to save all people' (p. 267) independent of material objects like a Bible ('part of Western intellectual property') and opium from the West. 


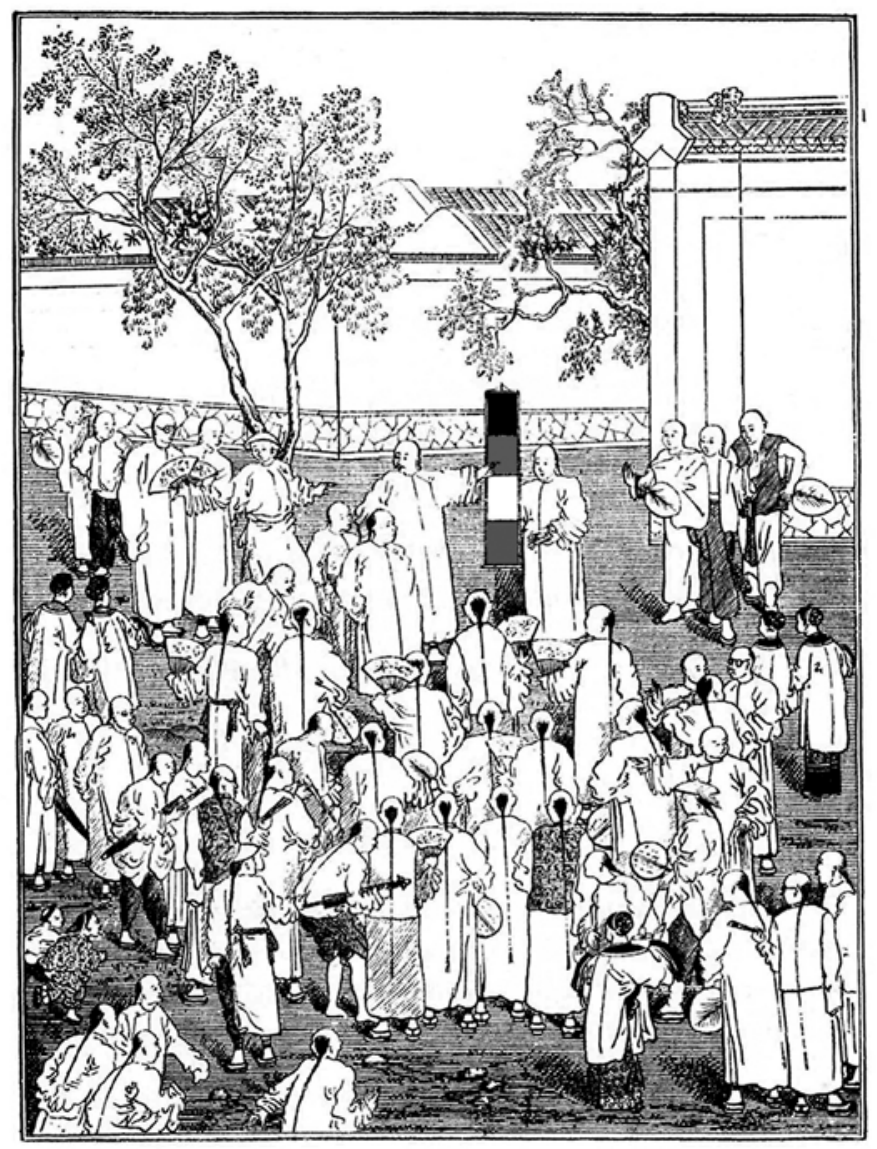

Ill. 3o. Open Air Preaching. China Inland Mission, 1892

Source: en.Wikipedia.org: 'Open Air Preaching' by a China Inland Mission, London.

avoid discussing the context or proportions of the behavior, thought or action: how many people in a given time or place can be "blamed"? And why is this relevant? Are they public or private persons? And so on.

An defender of the missionary position at the time, Spencer Hill, tried to be as concrete as possible in his research and concluded, therefore:

... the alleged insincerity of the Chinese proved on investigation to be due, partly to administrative impotence, partly and chiefly to violent action on our part and our practical encouragement of the unlawful trade. ${ }^{39}$

39 J. Spencer Hill, p. $9^{2}$. 
Lodwick also points to a specific kind of hypocrisy within the Christian circles. For the missionaries

opium addicts were untrustworthy and hence banned from church membership. With so many Chinese automatically excluded from the possibility of conversion, missionaries began to campaign against the drug. ${ }^{40}$

Although these missionaries acknowledged the disadvantage of the foreigner-opium association and although they must have had knowledge about the recent opium propaganda of colleagues and countrymen, they paradoxically identified the opium evils of Chinese social and political life with its non-Christian religion and morality. It was a consequence of their dominant position, spatially as well as culturally, as described clearly by Paul Cohen:

The missionaries lived and worked in the highly organized structure of the mission compound, which resulted in their effective segregation ... The missionaries really did not want to enter the Chinese world any more than they had to. Their whole purpose was to get the Chinese to enter theirs. ${ }^{41}$

In addition, Lodwick does not make obvious remarks about the era, the 19th-century, in which one revolutionary movement after the other developed and criminals - always in need of money-were found "all over the place". ${ }^{42}$ No obvious remarks were made either about the many underpaid corrupt bureaucrats, who were very helpful in spreading opium. Let us not forget either that the enormous extent of China does not allow for abstract generalizations.

Of course, Lodwick also "forgets" that in a rebellious and hunger-stricken China, it was very difficult for the provincial or imperial authorities (who nearly all forbade opium consumption as a luxury, not as a drug in medical treatment) to control the thousands of kilometers of coastlines or the criminal helpers of the foreign smugglers. ${ }^{43}$ Aside from the possibility that the Royal Navy was aiding these British and American smugglers. The existence of these categories and circumstances cannot be an excuse for foreigners to deliberately dope parts of a population. ${ }^{44}$ Ultimately, the

\footnotetext{
40 K. Lodwick, p. 181.

41 Quoted in Albert Feuerwerker's contribution to J. Fairbank (ed.), p. 172. Here also useful data about the many kinds of missionaries (Idem, p. 165-177).

42 D. Richards, p. 162.

43 A contemporary like J. Spencer Hill, p. 93, mentioned the difficulties that the central Chinese government was unable to control the provinces (Taiping, etc.) and that the English should help the central government. This was not done, and one gets the strong impression that the English did the reverse.

44 See C.Trocki (1999a), p. 124, about the exaggerations of the missionary Edkins.
} 
largest mistake of the foreign missionaries and their present historians was that only a very few individuals among them were brave enough to blame the foreign assault as such and blame the introduction of opium as a foreign assault on the minds of the Chinese.

What stopped them from doing this was their racist attitude. A few examples suffice here before I elaborate on this theme in the following section. In the swelling choir of moral anti-opium critics in the 1880s, Spencer Hill can be viewed as an honest man with a profound knowledge of the history and even economics of the opium traffic. But even he accepts highly dubious opinions as if 'the sentiments of morality and the powers of self-control are the weakest and most uncertain' among the Chinese:

In them the animal and sensuous elements of their nature are most fully developed, while their relish of momentary and immediate pleasures is particularly keen and regardless of the consequences, a combination of characteristics which renders them specially liable to, and unable to resist, any temptation that may be presented to them. ${ }^{45}$

This, however, was the reason for him to accuse the British ('a nation great and powerful', etc.) 'to take advantage of the weakness or the vice' of the Chinese instead of caring, protecting and helping these poor creatures to overcome their mental backwardness. (And to act like this, one is, of course, in need of an army of missionaries as, later, development workers in Western aid programs.)

Everywhere in the world opium or its derivatives have been prescribed for many ailments: in Western wars it is popular among soldiers as painkiller, etc. As a luxury, Westerners drank or injected the stuff; in India it was eaten:

The Chinese alone chose to consume the drug by smoking, and apparently this difference made the Westerners view the Chinese addicts with disgust.... opium was smoked in public dens. This visible use conflicted with Western standards of propriety and added to the foreigners' contempt for the Chinese. ${ }^{46}$

J. Spencer Hill, chapter 2 is probably the exception to the rule. He rightly bases his analysis of the "morality of the opium traffic" on: "The history of the trade in Opium ... was carried on mainly by British subjects with the support and protection of their government, in open defiance of the rulers of China and in direct contravention of the laws of that empire' (Idem, p. 29).

45 J. Spencer Hill, p. 56.

$46 \mathrm{~K}$. Lodwick, p. 4. This smoking story is a very strange one, because from the production side (the whole rather complicated treatment of poppy into consumable opium), 
Lodwick provides other astonishing examples of missionary tactics like the one of an archdeacon who told the Society for the Suppression of the Opium Trade: when preaching to the Chinese, 'when someone shouts out, "Who sells Opium?", my answer is, "Who smokes the Opium?" I have thus silenced them hundreds of times' ${ }^{47}$ A classical demagogic trick by equating producers with consumers.

This had apparently insufficient effect because in the 1890 s there was 'the almost universal Chinese idea' that the missionaries themselves were strongly involved in the opium business, so much so that the term 'Jesus opium' was in use everywhere. Small wonder that many missionaries found the opium question so embarrassing that they were reluctant to admit they were citizens of the British Empire or the USA and transformed themselves into Chinese, including a queue. Remember there was a treaty between the USA and China (1881), which prohibited Americans from engaging in the opium trade. The immediate response to the treaty was the racist Chinese Exclusion Act of 1882, a significant move in identifying a group seen as non-assimilable and threatening. ${ }^{48}$ No single American missionary organization protested against this law.

The position of the missionaries was not only determined by their perception of China and the Chinese or their intolerant behavior. According to many analysts one has to see their position within the imperialist exploitation system. America's ad hoc

colonial administration was often held together not by a strong civil service but by the army and the navy ... aided in considerable measure by a strong voluntarist ethic in the nongovernmental sector in which services were contracted out to missionaries, the YMCA, and other nongovernmental organizations. 49

The American empire had 900 missionaries in China in 1890, while 30 years later there were 14,00o which largely argued that the 'American

smoking is not the most obvious method, to say the least. Smoking in a pipe must have quite a different history in the Western world where the Portuguese and, in particular, the Dutch colonizers, who were the first to deal with opium as a luxury, were classical tobacco and pipe-smokers. Hashish as a luxury was smoked long before the East Asians knew of the stuff around the Mediterranean and in the Middle East. Both backgrounds should be combined in explaining why not only in China, but also in the whole of Southeast Asia the opium pipe was preferred and not eating it as in India. See D. Duco, passim.

47 Idem, p. 33, which is still a main "argument" of people like Harry Gelber (see previous chapter).

48 E. Cashmore (ed.), in the informative article 'Law: Immigration USA', p. 189.

49 A. McCoy, F. Scarano (ed.), p. 30 also for the following two quotations. 
empire should be moralized and turned into a moral state'. The meaning of this was crystal clear once an alternative opium policy was adopted, namely 'to assert American hegemony in East Asia to undermine the moral authority of the British and to aid the process of modernization in China'. As shown above, the Spaniards and Portuguese in the 16th and 17th centuries had already introduced fanatic conversion policies, and the Dutch and English Protestant colonizers did the same after they had conquered their Catholic predecessors. The New Imperialists USA, Germany and Japan again introduced a religious assault along with the military and opium one.

There remained differences between the nations in this respect. The British and American missionaries largely remained in the "opium-stricken" Chinese cities. The many strongly anti-foreigner resistance movements, including the Boxer Rising, encouraged them to do this. The Japanese tried to conquer whole provinces, as was shown above, and also produced propaganda for their national religion. The Germans, more heroic, tried to convert the peasants in the countryside. ${ }^{50}$ After 1933 their motivation to do this was clear and should be read in German:

Dem Deutschen liegt es im Blut, nicht auf die Verfeinerung des Volkes den größten Wert zu legen, sondern auf die Volkskraft. Er hat ein klares Auge dafür, daß in den Städten die Volkskraft verdorben und verbraucht wird, daß das Land die Städte überhaupt nur am Leben erhält. ('It runs in the Germans' blood not to insist so much on the cultivation of the people but on strengthening its immanent power. The Germans perceive it quite clearly that this Power of the people is spoiled and wasted in the cities, while the countryside is the force which nourishes the cities.) ${ }^{51}$

This application of the Blood \& Soil doctrine for Chinese aims suggests that in the countryside the peasant customs are still prevalent and the people control each other much more; somebody who aspires to become a Chinese Christian has a much higher "value" in the countryside than in the cities. There were complaints about how difficult it was to convert these peasants: apart from the obvious problems of poverty and lack of education, there were specifically the Communist attacks, who turned the mission into a hazardous venture.

Thanks to the studies of Wolfgang Eckart, realistic backgrounds are now known for these German missions. His detailed description of the

50 J. Müller's contribution to J. Richter (ed.), p. 94 ff.

51 Idem, p. 95. The Japanese "soul" was perceived as similar to the German 'Blut und Boden' (p. 101). 
Deutsches Schutzgebiet Kiautschou around the city of Tsingtao (Quingdao) on the coast of the Yellow Sea shows the sharp distinctions and mutual aversions between the poor Chinese and rich German military, bureaucrats and missionaries. ${ }^{52}$ This part of coastal China was "freely occupied" by and under the command of the German navy. ${ }^{53}$ The Europeans and Chinese lived quite isolated from each other. The former planned a kind of garden city with all possible luxury; it was even announced as a seaside resort. For the Chinese, the European contractors planned and built something very different. 'The development of the Chinatown Tapautau, however, ... was [around 1900] characterized by a government-inspired ghetto, an always increasing influx of indigenous laborers in far too few houses ... a continuous danger for the health of the inhabitants ... houses for more than 500 Chinese laborers ... new suburbs ...' which formed with the older buildings a hierarchy of poverty, dirt and misery. ${ }^{54}$ In the Germans own words, it was a 'Drecknest' with health conditions of an 'epidemic character', while in garden city Tsingtao, sicknesses decreased annually. Eckart continues with:

That the Chinese population was accused of being guilty itself for this may sound today as cynical, but was understandable in the colonial mentality of the European Herren of Kiautschou. ${ }^{55}$

This still sounds very cynical today, since the Chinese had to suffer health hazards, etc. thanks to the European actions, which were done on purpose. This went to further extremes: for example, the German marines nearly all had venereal diseases, but continued to infect Chinese women in remote villages. Willingly and knowingly, the German occupiers also organized an opium regime for the Chinese population:

Contrary to the directions of the International Opium Commission ... the opium consumption was not prohibited and even taxed. Also after 1909 every inhabitant of Kiautschou could get an Opiumschein [opium permit] for 1 dollar ... other revenues were gained by opening, controlling and taxing of opium dens. Between 1904 and 1907 the opium consumption in

52 W. Eckart, p. 458-505. In particular, he describes the health infrastructure in the "Europäerstadt Tsingtau" in contrast to the planning of the "Chinesenstadt Tapautau". This part of the coast was occupied by the German navy as revenge for the murder of two German missionaries (November 1897).

53 See S.G. Chen, p. 280 ff., $291 \mathrm{ff}$. about the remarkable move of the German to give their Schutzgebiet to Japan with far-reaching consequences also for the opium policy of this country (see chapter 27).

54 Idem, p. 462.

55 Idem, p. 464. 
Kiautschou increased from 6,575.47 kg to 8,697.97 kg. In 1908 there were $3,15^{0}$ addicted opium smokers registered. The Opium Law of 1912 did not alter this situation, but stabilized it. ${ }^{56}$

The large concentration of missionaries in Kiautschou stabilized this situation as well.

From Chinese sources there are only a few testimonies of the missionaries' personal activities. Sun Shuyun discovered the fate of a few of these German missionaries in the 1930 s and described them as sellers of 'the other opium', religion, 'the poison of the mind'. ${ }^{57}$ In the first thirty years of their stay in China, missionaries apparently converted fewer than 100 Chinese:

The Chinese were frightened of them, thinking the missionaries were devils, and their grey and blue eyes were due to their lack of nourishment, which they made up by eating the eyes of Chinese children. They stoned the missionaries, set fire to their houses, and petitioned local officials to throw them out. ${ }^{58}$ German missionaries achieved some success with the Miao tribe in Yunnan and Guizhou in the early 1910s. This mountain people was active in opium smoking and trade (see next chapter). The discrimination of the Miaos in Yunnan brought them together with the German 'foreign devils'. When the Red Army on its Long March arrived in a small country town, Shiqian, the settlement was thrown into panic. Soldiers found three German priests and some nuns. Two of them escaped, and the third died of hunger in captivity.

Another German priest, Rudolf Bosshardt, of the London-based China Inland Mission, was caught by a part of the 2nd Red Army and helped it to join with another part. He was released in 1935 after a long imprisonment and payment of \$20,00o silver dollars. Bosshardt's day-by-day account of his captivity is one of the most complete reports of the Long March, displaying the cruel reality of the Red Army's methods of supplying itself.

After about 1935 there were almost no Western missionaries left in this "mutually inimical" China in which they had become "foreign mud" for nearly all Chinese, Nationalists as well as Communists. They never returned. It has not been forgotten, however, how all these representatives of the Christian West perceived the Chinese as a detestable Yellow Race. The Reverend Arthur Smith provides the best introduction to the next paragraph with his elaborations on the Chinese 'physical vitality'.

\footnotetext{
56 Idem, p. 464 note 34.

57 S. Shuyun, p. 103.

58 Idem, p. 104.
} 
This vitality is for him excellent: A Chinese person recuperates very quickly from all the serious disasters in his time, which costs millions of people their life. However:

The only permanent and effective check upon the rapid increase of the Chinese population appears to be the confirmed use of opium, a foe to the Chinese race as deadly as war, famine, or pestilence. ${ }^{59}$

Herewith a new argument of doping Chinese is given, and the reverend's advice as panacea to 'the terrible vis inertia of Oriental apathy and fatalism - that dumb stupidity' is the action of 'some force from without'. As such, this influential religious official does not point to diplomacy. No, what is

needed by China ... is unrestricted intercourse, free trade, and the brotherhood of man. The gospel of commerce is the panacea for China's needs; more ports, more imports, a lower tariff and no transit taxes. ${ }^{60}$

Smith's bestseller The Uplift of China provides the outlines of an 'American Moral Empire' with the aim to 'lay deep the foundations of an Oriental Christian civilization'. ${ }^{61}$ This "empire" seems to be equivalent to America exploiting opium-stricken, pagan Chinese. At the end of the 19th-century, new imperialists still advertised the same ideas and practices as at the start, including the "free" and massive import of opium in exchange for silk, porcelain and tea, supported by a royal and republican navy (no diplomacy, but military power). The Chinese Exclusion Act (1882) covers both aspects: they are so inferior thanks to their opium smoking that they all must be returned to their own opium country. The victims are not only blamed, but also punished.

59 A. Smith (1894), p. 145.

60 Idem, p. 325, 326.

61 A. Smith (1907), p. X. I could not consult Ian Tyrrell's book with the effective title: Reforming the World. The Creation of America's Moral Empire (2010) but only a highly favorable review of Barbara Reeves-Ellington (H-Soz-u-Kult 03.06.2011). It is an up-to-date analysis of all possible American religious reform movements and organizations of the second half of the 19th-century. Their interconnectedness created the networks of empire that for Tyrell lie at the heart of American imperialism, even if reformers did not always meet their goals. Some are liberal (in the US sense), most fundamentalist sectarian. They all intersected with the state to promote the gospel of some American Dream which, therefore, always has to remain a dream. In Tyrrell's words it concerns 'the exercise of power under a shared moral and political order in which that power is the subject of multilateral contestation among nations and classes'. 


\section{Racism}

A major source of blaming victims was and, indeed, still is racism as developed in the wake of colonialism and imperialism of mainly the 19th-century. ${ }^{62}$ It is too popular a means to disqualify "The Enemy". No serious people today use "race" as a concept providing any knowledge about large groups of people, let alone individuals. Also with the new DNA knowledge and hype, most biologists - the traditional 19th-century and early 2othcentury sources of erroneous and dangerous race theories — rightly accept their own layman's knowledge of social, economic or cultural developments in societies. Nevertheless, it is, alas, appropriate to elucidate the pitfalls of racism as a function of nationalist enmity. This was the racism endemic from the middle of the European and American 19th-century. In hindsight, it was not surprising that it was exactly in new imperialist nations like the USA and Germany, who arrived too late for a profitable piece of the Eastern pie, that this imperialist racism had so much support. ${ }^{63}$

At the beginning of the 19th-century, the Chinese were seen as people who stupidly resisted "free trade", the mutual exchange of tea for opium or their conversion to Christianity. At the end of the century once their exploitation by the West had reached its peak, they were seen as the most terrible enemies of mankind, who contaminated the human race with their opium, who were ready to conquer and enslave the rest of the world and had already sent thousands of emigrants to the USA, other Western countries and their colonies in order to steal "well" paid jobs, forming at the same time a secret army preparing to conquer the West, and so on.

This perception was accompanied everywhere in the West and their colonies (Australia, New Zealand, etc.) by the slogans of the Yellow Danger, La Race Jaune, the Yellow Specter, het Gele Gevaar, the Gelbe Gefahr, or the Yellow Terror and the Yellow Race. They were conjured up in the same way as antisemitism was spread, namely, by means of terrifying anti-Chinese cartoons, writings, pogroms or movies. Most of the pictures were of addicts sucking on their pipes in opium dens. In particular, union leaders

62 See E. Cashmore (ed.), p. 264-279 as a reasonable but outdated analysis of race and racism. Racism was also a main motive in 16th-century colonialism and missionary activities (the Roman Catholic Spain and Portugal), but it was not yet combined with nationalism and state-capitalist monopolies as in the 19th-century dominated by Protestant/ Calvinist countries like the English, Dutch and Americans.

63 For the following see U. Mehnert, the detailed Wikipedia article "Yellow Peril" with many present-day examples. 


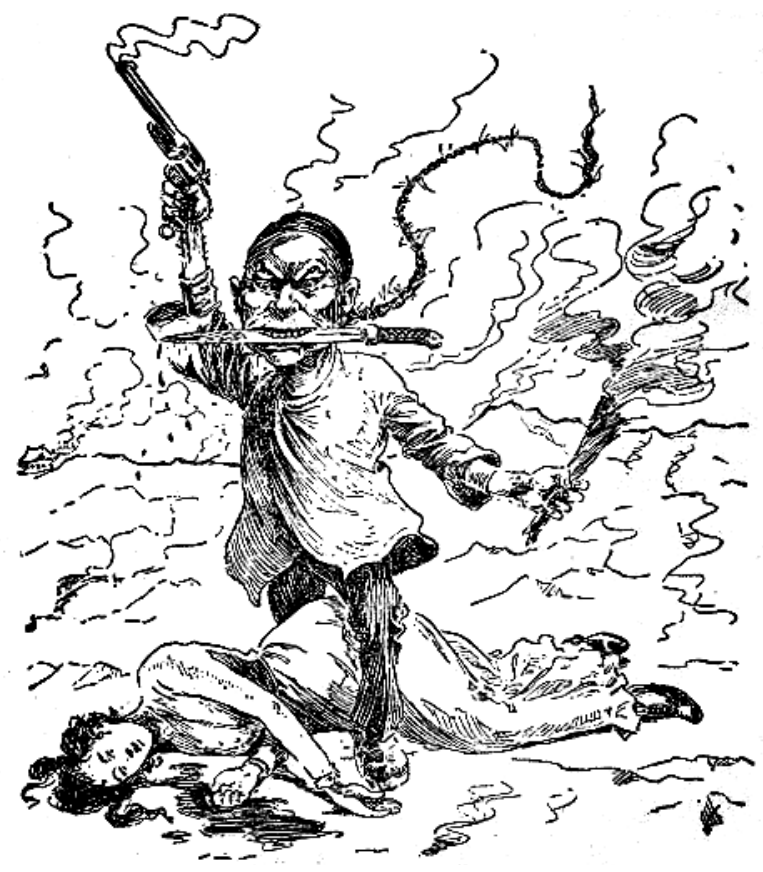

Ill. 31. The Yellow Terror ca. 1900

Source: en.Wikipedia.org 'Yellow Terror in All his Glory'

feared that the Chinese would undermine American or British labor (the Chinese population reached a peak of 2,419 in 1931 in the whole of Britain!). The Chinese were also accused of introducing iniquitous practices such as gambling and opium smoking. Sex was added in the classical manner to these fear elements by pointing to miscegenation. This was considered immoral, unnatural and endangering The Empire. ${ }^{64}$

64 For this kind of racist problems in Britain, see the interesting Sascha Auerbach. See also the review of this book by David Lloyd Smith (who does not know that Sascha is a well-known Jewish female name) in: H-Net Reviews (Jan. 2010). He made the remark that a highly influential racist book of Sax Rohmer, Dope: A Story of Chinatown and the Drug Traffic (1919) 'is a repellent novel-racist, anti-Semitic, and xenophobic, and mired in reactionary politics', but not a sinophobic work. Jews are described by Rohmer 'as the primary threat to the hegemony of the Anglo-Saxon race'. To substantiate this, he quotes from another Rohmer book describing a positive element of the 'Chinese heart', i.e. a deep distrust of the police. This is not convincing, when no further qualification is given. In addition, one can ask which police is distrusted: if it is Chinese police, it is difficult to suppose sinophobia. If it is the white police of the International Settlements (which must be the case here), then the quotation points to remarkable practices of sinophobia: considering 
Germany and the USA were the main sources of this racism, and it is highly symbolic that the German Emperor Wilhelm II could write to the President of the USA at the time, Theodore Roosevelt (September 1905):

I foresee in the future a fight for life \& death between the "White" and the "Yellow" for their sheer existence. The sooner therefore the Nations belonging to the "White Race" understand this \& join in common defense against the coming danger, the better. ${ }^{65}$ Roosevelt was, indeed, the right address. Reflecting on what might cause 'new nations of an old stock to spring up in new countries' like Australia and the United States, he expressed the opinion:

'the peopling of the great island-continent with men of the English stock is a thousand-fold more important than the holding of Hindoostan for a few centuries.' [It was the] 'ethnic conquest' of a territory ... The presence of the 'Chinaman' [whether in Australia or the United States would be] 'ruinous to the white race' [but these democracies] 'with the clear instinct of race selfishness, saw the race foe, and kept out the dangerous alien.' 66

A large part of Australia has a tropical climate, and at the time it was difficult to get a "white" labor force for the plantations and similar work. These entrepreneurs hired Chinese and other Asians. As soon as these newcomers were noticed, they became competitors of the whites, and like in the US, the Australian trade unions initiated strong racist actions: for them the Chinese were of a 'depraved and dissolute' race; or 'The risks to white male health were alcohol, opium and Asian prostitutes', and so on. ${ }^{67}$ The liberal (Australian definition) president, Samuel Griffith, immediately changed laws so that Asians could be extradited (1892).

Particularly in the USA, these images and opinions were combined with the slave-like situation of most Chinese immigrants working in the mines or on the railway projects. Since that time, opium addiction has been described in the United States as 'un-American' and 'non-Western' ${ }^{6}$

Chinese as pariahs 'who may therefore be robbed, beaten and even murdered by his white neighbours with impunity.'

65 Quoted by U. Mehnert, p. 9.

66 Quoted by W. Anderson, p. 254.

67 Idem, p. 88. See also p. 9o: A Watson told: 'The yellow, the brown, and the coppercoloured are to be forbidden to land anywhere.'; the chief objection to Chinese immigration was 'entirely racial' (Senator Pearce); the Chinese 'cannot mix with us. We know from the teachings of science that they cannot' (Senator Smith), etc.

68 D. Musto, p. 2; U. Mehnert, p. $49 \mathrm{ff}$. points to the fact that Chinese in the USA of the 1870 s concern about $4 \%$ of the total, mainly European immigrants of 2.8 million people. The always highly racist trade unions in the USA (led by Jews like Samuel Gomperz) were the source of the anti-Chinese (later anti-Japanese) actions. Japanese were attacked from the 1890 s onwards, but their immigration was much lower than the Chinese: $0.001 \%$ of the 
It led to a heavy repression of Chinese in this country and even their extradition around 1910. In the end an "explanation" for all this was found in the doctrine of the "Yellow Race", a non-doctrine reproduced in all sorts of pejorative slogans, rationalizations and chimeras.

In 1868 the racist Henri George (later famous for his Progress and Poverty, 1879) published his reasons why 'pagan, untrustworthy, voluptuous, cowardly and cruel' Chinese should be excluded in order to save 'the racial homogeneity' of the Americans. ${ }^{69}$ Another provocative book was The Chinese Invasion (H. West, 1873) in which the Chinese were compared to the 'great plagues [which] overran Egypt'; pogroms against the Chinese were regular events like the one in Tacoma, Washington (1877) in which a whole Chinese quarter was burned to the ground, etc. A few years later the Chinese Exclusion Act appeared. Around 1895 the anti-Chinese and anti-Japanese propaganda everywhere reached its high point.

After the turn of the century, the phrase "Yellow Peril" was daily food for the readers of the Hearst newspapers in the USA. An influential US evangelist, G. Rupert, preached about the same peril and warned in 1911 of the assault on the West by China ("... only Jesus Christ can stop these attacks"). In 1914 the famous author Jack London wrote about the coming world hegemony of China, as did the novelist Nowlan with his novel Armageddon (1928) at the moment China was close to a total collapse!

In Europe the situation was not very different. Thanks to their continuous resistance against British, French, etc. assaults, the Chinese were characterized in the 19th-century publicity as unreliable, cruel and sly; their nation as reactionary and despotic. And nearly always these qualifications were followed by references to their gambling and opium addiction. ${ }^{70}$ The German Emperor Wilhelm II promised his nation that he would eradicate this gelbe Gefahr (Die Hunnenrede, July 19oo) ${ }^{71}$; in

whole US population. From then on the Chinese stereotypes became similar to the Japanese ones. They also became 'inferior, unreliable and tricky' (Idem, p. 55). Japan, however, received many more comments because a political-military development of becoming a world power accompanied the racist discourse.

69 U. Mehnert, p. 52.

70 A well-known German commentator on world politics, Paul Dehn, used these qualifications (1905) referring to western 'experts of the Far East'. U. Mehnert, note 7 p. 22.

${ }^{71}$ In this notorious speech to a German expedition army to the Far East, aimed at crushing the Boxer Rebellion, the German Kaiser compared this 'Prussian Christian army' with the revenging Huns of Atilla. He ordered them not to take prisoners and behave as ruthlessly as possible, 'so that the name of Germany in China is feared in a way that never again a Chinese tries to squint at a German'. A classical example of how racist remarks were transformed in disqualifications of The Enemy is that "Huns" became since this speech the name for barbarous Germans during World War I. 
England, M. Shiel published the bestseller The Yellow Danger (1897) about the murder of two missionaries by Chinese.

There are remarkable parallels with present publicity because, for instance, Rupert preached what he called 'British Israelism', while now Zionist writers like Margalit or Morris and Samuel Huntington and other Occidentalism writers warn about global attacks by Islam and China on the West; new US evangelists preach war against the modern China. Mehnert also points to the strong parallels between the Yellow Race slogans and the present concepts like "the Asian Challenge" or "Japanese Challenge" which ask for "Our" response or directly for a new war against Islam or whatever enemy is needed to assuage the "Western" bad conscience. ${ }^{72}$

The excuse that the 'Yellow Race' was specifically attracted or suited to opium possibly cancelled Western guilt. It was soon mixed up with all kinds of Orientalisms. Here are two examples. An interesting detailed article in a famous (pre-war) encyclopedia states

that behind the opium problem there is a fundamental divergence of attitude between East and West. The custom of eating and smoking opium has by this time become deeply ingrained in the social fabric of the eastern countries - so deeply ingrained in fact that it cannot readily be eradicated without the full cooperation of the western powers. ${ }^{73}$

The misleading reference to the "age-old use of opium" in China accompanies the accusation that 'colonial interests' exploited these 'eastern habits'!

A variant on what the opium dealers like the Jardines, Mathesons or Sassoons told the world as quoted at the start of this chapter provides the next example:

It is true that opium is not likely to become popular among an active and industrious race like the Anglo-Saxon, whose preference must always be for the more potent, though less permanent stimulus, of ardent spirits, the "gross and mortal enjoyments" of which are far more suitable to the character of that race than the "divine luxuries" of opium ... Orientals ... will choose the stimulant which multiplies and gives a livelier coloring to ...

72 The present Samuel Huntington crusade is an old one. Already, Hugh Lusk published in the North American Review (1907) an article titled 'The Real Yellow Peril' in which he states that the thread of the Asian people is not so much a military or economic thread: 'The real peril is to be found ... in the collision and competition of civilizations'. Quoted in U. Mehnert, p. 53 .

73 Encyclopaedia of the Social Sciences, vol. XI, p. 472 (1949) clearly written around 1935 by H.H. Moorhead and H. Tobin. 
ideas, rather than that which ... excites to muscular exertion and boisterous mirth. ${ }^{74}$

Of course this is phraseology and has nothing to do with the practice physicians experienced in their therapeutic observations and written down 20 years earlier, let alone what numerous observers have reported since the 16 th-century:

The greatest sufferings ... are those which attend the state of depression, always existing when its direct influence is no longer felt. There are excessive restlessness, a universal and indescribable uneasiness, feelings of intolerable distress, especially in the epigastrium and lower extremities, an irksome sense ... of incapacity both for intellectual exertion and for mental or emotional enjoyments ... ${ }^{75}$ and so on.

Indeed, the "Anglo-Saxon Race" was vulnerable to 'more potent' drugs which became the derivatives of opium like heroin and morphine.

The intellectual level of discourses about race and drugs in the United States, which had such far-reaching effects, displayed strange mixtures of negative and positive elements. For example, certain drugs were dreaded because they seemed to undermine specific restrictions keeping groups and races under control:

cocaine was supposed to enable blacks to withstand bullets which would kill normal persons and to stimulate sexual assault. Fear that smoking opium facilitated sexual contact between Chinese and white Americans was also a factor in its total prohibition. ${ }^{76}$

Every racial group received so its "prescription" largely adjusted to the political demands of the day.

After about 1890 it was clear enough that Japan, contrary to China, was achieving a prominent role in world politics and becoming an imperialistic competitor of the Western powers, including Russia. In the Yellow Race doctrine, however, the Chinese and Japanese were lumped together. That situation had to change, however, as soon as new friend-enemy relations developed. The most prominent among them was the Berlin-Tokyo axis of Nazi Germany against its strongest enemy at that time, England and its British Empire.

German racial theorists, earlier in the forefront of the Yellow Danger (Gelbe Gefahr) publications, had to rewrite their textbooks into a remark-

\footnotetext{
74 Quoted in C. Terry, M. Pellens, p. 95.

75 Quoted from dr. G. B. Wood (1856) in Idem, p. 138.

76 D. Musto, p. 244, 245 .
} 
able mixture of the classical position and a "Yellow Lovestory". Still, the 'Northern Germanic Race' must remain in the leading position, which led to a highly ambiguous treatment of the East.

So, in his historical 'applied racial theory', Heinrich Wolf fully agrees with the policies of Australia and New Zealand, 'where the indigenous people are fully destroyed by the whites', and that they strongly oppose the immigration of Chinese coolies and Japanese peasants: it is, indeed a struggle between 'Germanisation or Orientalisation'. ${ }^{77}$ Wolf's proto-Nazi racial stand was soon followed by one of its prominent ideologues.

In his Mythus (1930, etc.) Alfred Rosenberg was not only enthusiastic about the impact of Confucianism and Taoism on the racial characteristics of the Chinese and their society. He also gave a long overview of the British opium attacks, which was introduced by some general remarks on the economic imperialism of the West that

cotton and opium, waste-products of Europe, could infiltrate into China to destroy first the equilibrium of Chinese life in coastal cities and later every time farther into the interior ... even learned Chinese started to beautify their homes ... with Western kitsch ... but protests came from Chinese and Japanese intellectuals ... to start a movement of racial renewal and liberation of the East ... Today China has lost its typical mythical ideal ... One may hope that missionaries, opium dealers and dark adventurers have to leave China soon ... Like the large movement of renewal in Germany, China struggles for its myth, for its race and its ideals against the commercial race which dominates today all stock-markets and the deeds of nearly all governments. ${ }^{78}$

The Yellow Race doctrine is flexible enough to be used in the game "the enemy of my enemy is my best friend". What is to be done, though, when both friends and enemies disappear like opium smoke? After the Japanese were conquered in 1945, happily for the heirs of the old empires, the rise of Mao and its "communism" in 1949 could keep the doctrine fresh and alive.

77 H. Wolf, p. 325. Wolf has headed a paragraph 'Die gelbe Gefahr' referring to Houston Chamberlain's 'Grundlagen des 19.Jahrhunderts' and, in particular, Wilhelm Schallmeyer's influential 'Vererbung und Auslese' which accuses the British and French of occupying China 'in a barbaric way', whereupon it was subjected to 'das schädliche Opiumlaster' (p. 327 ; 'the noxious sin of opium').

78 A. Rosenberg, p. 652-654. 